\title{
PENINGKATAN PENGETAHUAN MANAJEMEN USAHA DENGAN MENGGUNAKAN APLIKASI ANDROID (AKUNTANSI UMKM) PADA PAGUYUBAN IBU-IBU PEDAGANG KELONTONG KELURAHAN MARGADANA
}

\author{
Nurul Mahmudah ${ }^{1}$, Arifia Yasmin ${ }^{2}$, Ririh Sri Harjanti ${ }^{3}$, \\ Krisdiyawati $^{4}$, Dewi Sulistiyowati ${ }^{5}$ \\ ${ }^{12345}$ Program Studi DIII Akuntansi Politeknik Harapan Bersama \\ Jl. Mataram No. 9 Tegal, Telp (0283) 352000 \\ Email: nurulmahmudah1989@gmail.com
}

\begin{abstract}
Abstrak
Tujuan dalam kegiatan pengabdian kepada masyarakat ini adalah masyarakat mampu melakukan pencatatan keuangan dengan tertib, para UMKM dapat mengetahui kondisi keuangan sekaligus perkembangan usahanya memalui aplikasi android "Akuntansi UMKM", mampu membuat keputusan bisnis penting seprti pembelian aset baru dan rencana pengembangan usaha serta mampu membuat manajemen usaha keuangan dengan baik. Khalayan kegiatan pengabdian masyarkat ini adalah para ibu-ibu pedagang klontong di Kelurahan Margadana Kota Tegal. Adanya praktik pencatatan laporan keuangan dengan menggunakan aplikasi android ini untuk meningkatkan kemampuan ibu-ibu pedang klontong dalam membuat pencatatan laporan keuangan yang semakin mudah. Jarak tempuh kampus degan khlayak sasaran kurang lebih sekitar $5 \mathrm{~km}$ dapat ditempuh dengan menggunakan transportasi motor dan mobil. Metode atau cara yang digunakan dalam Kegiatan Pengabdian pada Masyarakat ini adalah pertama dengan menggunakan metode survei, dimana tim melakukan survei langsung ke lokasi untuk pengumpulan data awal. Selain melakukan survei, tim juga melakukan observasi dan wawancara. Observasi dan wawancara ini dilakukan pada tahap awal yaitu dalam rangka mengumpulkan data dan mencari permasalahan sebelum memutuskan kegiatan pengabdian seperti apa yang sesuai dengan khalayak sasaran. Wawancara dilakukan dengan pihak Kelurahan Margadana Kota Tegal.
\end{abstract}

Kata kunci : UMKM, Aplikasi, Android

\section{PENDAHULUAN}

Akuntansi adalah suatu proses mengidentifikasi, mengukur dan melaporkan informasi ekonomi untuk memungkinkan dilakukannya penilaian dan pengambilan keputusan secara jelas dan tegas bagi pihak-pihak yang menggunakan informasi tersebut.Dari pengertian di atas terkandung tujuan utama akuntansi adalah menghasilkan atau menyajikan informasi ekonomi (economic information) dari suatu kesatuan ekonomi (economic entity)kepada pihak-pihak yang berkepentingan. Oleh karena itu informasi akuntansi itu pada dasarnya menyajikan informasi ekonomi kepada banyak pihak yang memerlukan, sehingga akuntansi juga sering disebut dengan bahasa dunia usaha. Mengapa demikian? Karena akuntansi merupakan alat komunikasi dan informasi bagi pihak-pihak yang memerlukannya. Hal ini bukanlah kata-kata yang berlebihan untuk para generasi millenial yang selalu hidup menggunakan smartphone. Smartphone saat ini bisa 
digunakan untuk memenuhi berbagai kebutuhan, termasuk untuk proses akuntansi bisnis dengan aplikasi akuntansi.

Pada UMKM pengelolaan/kepemimpinan biasanya dilakukan sendiri oleh pemiliknya sehingga tidak dapat terhindarkan masalah perangkapan jabatan. Pemilik bertindak juga sebagai pengelola utama usaha sekaligus sebagai manajer produksi, sebagai manajer keuangan, sekaligus juga sebagai manajer pemasaran. Hal tersebut membuat pengelolaan usaha pada UMKM juga tidak bisa maksimal. Karena kemampuan orang tidak bisa menguasai berbagai hal dalam waktu yang bersamaan.

Perkembangan UMKM yang saat ini semakain berkembang maka para pengusaha berusaha untuk membuat sebuah kreativitas baik dalam hal produk maupun pemarannyanya, dalam hal ini setiap pengusaha dituntut untuk dapat melakukan pembukukan yang mudah agar mampu memperlancar jalannya usaha sehingga nantinya mampu memisahkan mana harta pribadi dan mana modal, untuk itu dalam kegiatan pengabdian ini mampu memberikan pengetahuan mengenai pembukuan akuntansi dengan menggunakan aplikasi android akuntansi UMKM. Perkembangan UMKM yang begitu pesat harus didorong dengan adanya manajemen usaha yang mampu mendampingi para pedagang yang nantinya mampu menjalankan eksistensi keberadaan aplikasi android akuntansi UMKM ini agar dapat digunakan dengan sebaik-baiknya. Keberadaan pedagang kelontong dikelurahan margadana cukup banyak akan tetapi mereka masih menggunakan sistem manual, oleh karena itu dengan adanya aplikasi android Akuntansi UMKM ini mampu memudahkan mereka untuk melakukan pembukuannya.

\section{METODE}

Adanya pemaparan mengenai manajemen usaha dan praktik pencatatan laporan keuangan dengan menggunakan aplikasi android akuntansi UKM. Adanya bentuk-bentuk pelatihan berupa praktek pengisian pencatatan laporan keuangan dengan menggunakan aplikasi android akuntansi ukm, yang beralamat di kelurahan margadana, Jarak tempuh kampus dengan khalayak sasaran kurang lebih $5 \mathrm{~km}$ yang dapat ditempuh menggunakan trasportasi motor dan mobil.

Metode atau cara yang digunakan dalam Kegiatan Pengabdian pada Masyarakat ini adalah pertama dengan menggunakan metode survei, dimana tim melakukan survei langsung ke lokasi untuk pengumpulan data awal. Selain melakukan survei, tim juga melakukan observasi dan wawancara. Observasi dan wawancara ini dilakukan pada tahap awal dalam rangka mengumpulkan data dan mencari permasalahan sebelum memutuskan kegiatan pengabdian seperti apa yang sesuai dengan khalayak sasaran. Wawancara dilakukan dengan pihak kelurahan margadana kota tegal.

Berikut adalah tahapan-tahapan yang dilakukan dalam melaksanakan Kegiatan Pengabdian Kepada Masyarakat:

1. Melakukan studi literatur mengenai manajemen usaha dan pencatatan laporan keuangan serta perlu dilakukannya usaha untuk meningkatkan pengetahuan tersebut dalam bentuk kegiatan Pengabdian Kepada Masyarakat.

2. Pemilihan khalayak sasaran ibu-ibu pedagang/pengusaha dikelurahan margadana karena hal ini masih banyak para pedagang kelontong yang masih menggunakan pencatatan secara manual bahkan masih banyak ibu-ibu pedagang yang belum memahami bagaimana cara pencatatan laporan keuangan.(hasil wawancara dengan seklur pihak kelurahan margadana).

3. Dilakukan observasi awal ke lokasi kelurahan margadana. Obervasi ini dilakukan untuk mengumpulkan data awal mengenai temuan permasalahan yang dihadapi. Selain itu juga dilakukan wawancara dengan pihak-pihak terkait sehubungan dengan temuan masalah dan keinginan tim untuk melakukan kegiatan Pengabdian Kepada Masyarakat di lokasi tersebut.

4. Menyusun proposal kegiatan Pengabdian Kepada Masyarakat. 
5. Pelaksaaan kegiatan pengabdian kepada masyarakat di kelurahan margadana, dengan tema "Peningkatan Pengetahuan Manajemen Usaha Dengan Menggunakan Aplikasi Android (Akuntansi UKM) Pada Paguyuban Ibu-Ibu Pedagang Kelontong Kelurahan Margadana.".

6. Menyusun laporan kegiatan Pengabdian Kepada Masyarakat.
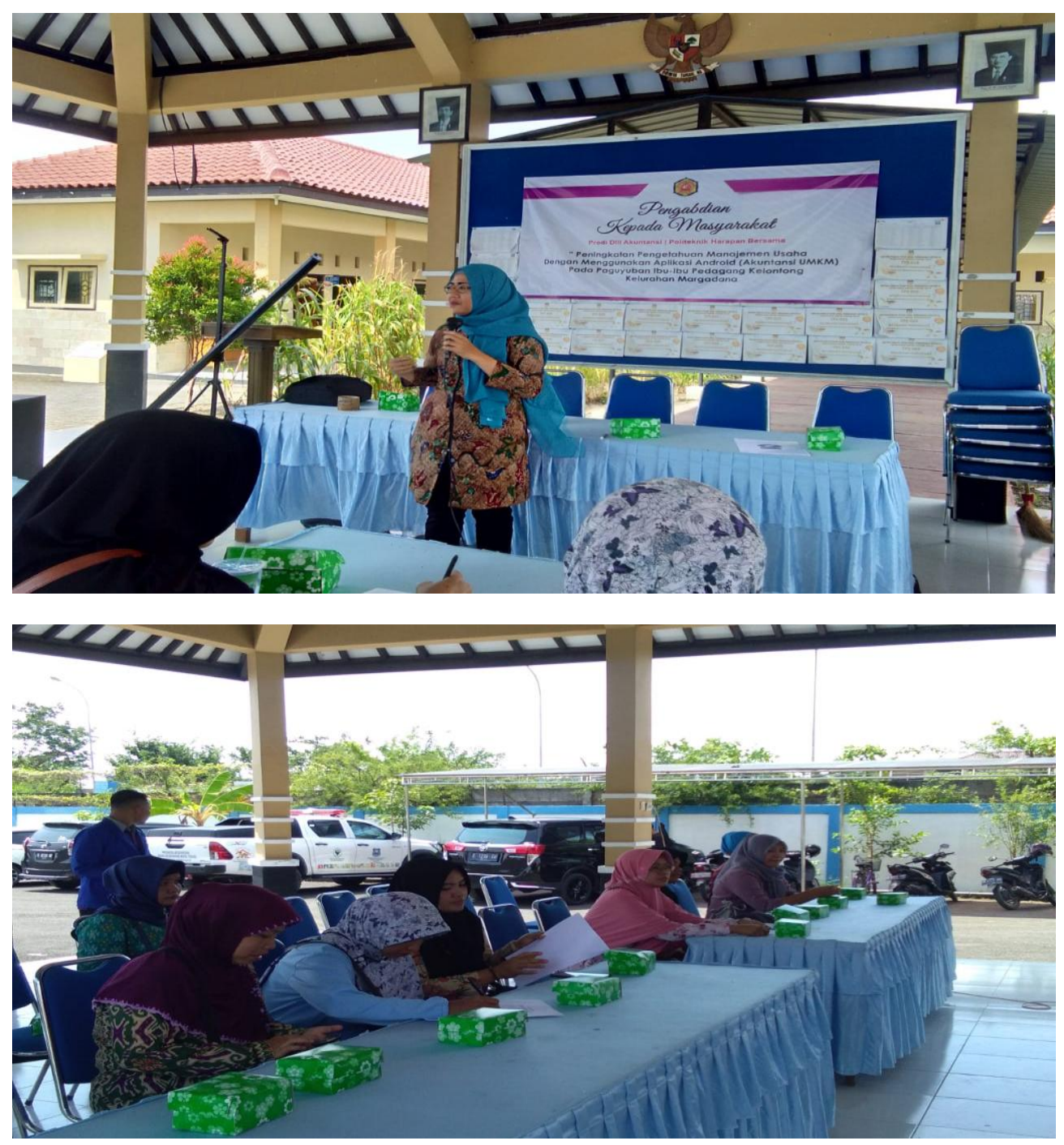

Gambar 1 Pemaparan Materi pencatatan laporan keuangan dengan menggunakan aplikasi android akuntansi ukm

\section{TNJAUAN PUSTAKA}

Manajemen adalah seperangkat kegiatan berupa perencanaan dan pengambilan keputusan, pengorganisasian, pengarahan dan pengendalian yang diarahkan kepada sumberdaya organisasi (manusia, finansial, peralatan fisik dan informasi) dengan tujuan untuk mencapai tujuan organisasi dengan cara berdaya guna dan berhasil guna (Stoner, 2009). Fungsi-fungsi manajemen yang harus dilakukan adalah fungsi perencanaan, fungsi pengorganisasian, fungsi pengendalian serta fungsi pengawasan.Semua fungsi ini harus dilakukan agar perusahaan dapat mengoptimalkan semua sumberdaya yang ada dalam perusahaan sehingga tujuan perusahaan dapat tercapai.

Perspektif manajemen usaha kecil relatif sedikit berbeda dari manajemen usaha skala besar. Perbedaan yang dimaksud antara lain pada perusahaan besar dan mapan antarfungsi dan tugas manajer telah dipilah-pilah sedemikian rupa sesuai strategidan struktur organisasi. Pada usaha kecil dimana seluruh sumberdaya sangat terbatas, fungsi dan 
tugas seorang manager berbau rmenjadi satu karena keterbatasan sumber daya. Manajer pada usahakecil seringkali juga merupakan pendiri atau pemilik. Manajemen keuangan adalah suatu proses dalam pengaturan aktivitas atau kegiatan keuangan dalam suatu organisasi dimana di dalamnya termasuk kegiatan perencanaan, analisis dan pengendalian terhadap kegiatan keuangan.

Manajemen keuangan dapat diartikan pula sebagai seluruh aktivitas atau kegiatan perusahaan yang berhubungan dengan upaya untuk mendapatkan dana perusahaan dengan meminimalkan biaya serta upaya penggunaan dan pengalokasian dana tersebut secara efesien dalam memaksimalkan nilai perusahaan.Fungsi utama dari manajamen keuangan adalah (1) kegiatan mencari dana (obtain of fund) yangditujukan untuk keputusan investasi yang menghasilkan laba,dan (2) kegiatan menggunakan dana(allocation of fund); dan (3) kegiatan mendistrubusikan laba sebagai hasil kegiatan operasi. Agar dapat mengambil keputusan keuangan yang tepat maka seorang manajer keuangan wajib mengetahui tujuan yang ingin dicapai. Secara normatif tujuan keputusan keuangan perusahaan adalah memaksimalkan nilai perusahaan.. Tujuan ini identik dengan meminimalkan biaya modal yang harus dikeluarkan oleh perusahaan.

Pengelolaan manajemen usaha dibutuhkan dalam konteks internal perusahaan, agar perusahaan benar-benar memiliki arah dalam menjalankan usaha, terukur, dan terencana dengan baik. Perencanaan usaha juga akan menjadi "controlling tools", apakah dalam perjalanannya nanti, bisnis yang dijalankan berada dalam lineyang benar atau tidak.Terutama dalam bisnis yang relatif baru, penuh dengan kreatifitas, perencanaan usaha juga semakin dibutuhkan. Beberapa manfaat yang diperoleh dari pengelolaan usaha adalah:1.Memilih bisnis yang feasibel untuk dijalankan berda sarkan studi kelayakan yang dilakukan 2. Memiliki usaha yang berbadan hukum jelas 3. Memiliki laporan keuangan (bermanfaat untuk kelangsungan usaha, keuntungan optimal, pengajuan kredit) 4. Memiliki perencanaan pengembangan dan operasional usaha yang jela

\section{HASIL DAN PEMBAHASAN}

Kegiatan Pengabdian Masyarat ini dilaksanakan pada kelurahan margadana kota tegal. Kegiatan pengabdian masyarakat kali ini merupakan pertama yang dilakukan di kelurahan margadana kota tegal. Pelatihan ini di hadiri oleh kurang lebih sekitar 15 orang. Kegiatan ini disambut positif oleh pihak kelurahan margadana dan ibu-ibu pedagang klontong yang bergabung dalam kegiatan pelatihan tersebut, mengapa demikian? Karena pada dasarnya para ibu-ibu pedagang klontong sangat membutuhkan informasi mengenai manajemen usaha dan pencatatan mengenai pembukuan laporan keuangan secara praktis dan mudah, hal ini didasasri oleh banyaknya perkembangan teknologi yang semakin canggih. Dalam hal ini kami selaku tim pengabdian kepada masyarakat berharap dengan adanya kegiatan pelatihan mengenai praktik pencatatan laporan keuangan dengan menggunakan aplikasi android akuntansi ukm ini mampu memberikan manfaat dan pemahaman yang sangat mendalam khususnya mengenai pencatatan laporan keuangan. Kegiatan pengabdian masyaraka ini banyak sekali ibu-ibu pedagang klontong yang kreatif memberikan pertanyaanpertanyaan serta harapan untuk diadakannya tindak lanjut dari kegiatan pelatihan pembukuan ini berupa bimbingan teknis yang lebih mendalam tentang pelatihan pembukuan laporan keuangan.

Adapun beberapa agenda yang direncanakan dalam kegiatan pengabdian masyarakat diantaranya :

\begin{tabular}{lll}
\hline No. & Acara & Keterangan \\
\hline 1. & Pembukaan Oleh MC & Panitia \\
2. & Sambutan SekLur Kelurahan Margadana & Bapak Ivan \\
& Kota Tegal & \\
3. & Sambutan Tim PKM & Ibu Nurul Mahmudah \\
4. & Materi Pelatihan & Ibu Dewi Sulistyowati \\
5. & Dokumentasi & Mas Juli \\
6. & Penutup oleh MC & Panitia \\
\hline
\end{tabular}


Adapun materi yang disampaikan dalam kegiatan pelatihan pengabdian kepada masyarakat yaitu :

Contoh Kasus Laporan Keuangan UKM Warung

Pada Bulan Juni Ibu Raisa Ingin membuka Warung atau Toko Kelontong, berikut transaksi yang terjadi pada usaha Ibu Raisa.

Kasus :

1. Ibu Raisa punya Uang 10 Juta dan berencana membuat warung yang di beri nama"Warung Murah" pada tanggal 1 Juni 2016.

2. Tanggal 2 Ibu Raisa melakukan pembangunan toko senilai 3 juta rupiah. Pembelian Satujuta dibayar cash dan 2 juta di peroleh melalui pinjaman pada toko bahan bangunan.

3. Tanggal 8 Toko selesai dan Ibu Raisa membeli lemari Etalase sebanyak 2 unit dengan harga masing-masing Rp. 750.000 .

4. Tanggal 9 Ibu Raisa melakukan pembelian barang sejumlah Rp. 5.000.000 dengan pembelian tunai sebesar Rp. 4.000.000 dan pinjaman dari toko Rp. 1.000.000.

5. Tanggal $10 \mathrm{Ibu}$ Raisa Membeli Meja Senilai 300.000 dan ATK senilai 100.000.

6. Tanggal 11 Ibu Raisa mencoba membuka Rekening Bank dengan setoran Awal 500.000.

7. Tanggal 17 Terjadi transaksi Penjualan Tunai sebesar 450.000.

8. Tanggal 21 Penjualan 1.000 .000 dengan keterangan Tunai, 750.000 dan sisanya dipinjamkan.

9. Tanggal 29 Membeli Barang Senilai 3.000.000 tunai.

10. Tanggal 31 Membayar Utang 500.000 dan menerima Pembayaran Piutang 100.000

Dalam pembuatan jurnal, berikut tabel Jurnal Umum-nya.

\begin{tabular}{|c|c|c|c|c|}
\hline TG & KETERANGAN & REF & DEBET & KREDIT \\
\hline 1 & $\begin{array}{l}\text { KAS } \\
\text { MODAL }\end{array}$ & & $10,000,000$ & $10,000,000$ \\
\hline 2 & $\begin{array}{l}\text { BANGUNAN } \\
\text { KAS } \\
\text { HUTANG USAHA }\end{array}$ & & $3,000,000$ & $\begin{array}{l}1,000,000 \\
2,000,000\end{array}$ \\
\hline 8 & $\begin{array}{l}\text { INVENTARIS USAHA } \\
\text { KAS }\end{array}$ & & $1,500,000$ & $1,500,000$ \\
\hline 9 & $\begin{array}{l}\text { PERSEDIAAN } \\
\text { BARANG KAS } \\
\text { HUTANG USAHA }\end{array}$ & & $5,000,000$ & $\begin{array}{l}4,000,000 \\
1,000,000\end{array}$ \\
\hline 10 & $\begin{array}{l}\text { PERALATAN TOKO } \\
\text { PERLENGKAPAN } \\
\text { TOKO } \\
\text { KAS }\end{array}$ & & $\begin{array}{l}300,000 \\
100,000\end{array}$ & 400,000 \\
\hline 11 & $\begin{array}{l}\text { BANK } \\
\text { KAS }\end{array}$ & & 500,000 & 500,000 \\
\hline 17 & $\begin{array}{l}\text { KAS } \\
\text { PENJUALAN }\end{array}$ & & 450,000 & 450,000 \\
\hline
\end{tabular}




\begin{tabular}{|c|c|c|c|}
\hline 21 & $\begin{array}{l}\text { KAS } \\
\text { PIUTANG } \\
\text { USAHA } \\
\text { PENJUALAN }\end{array}$ & $\begin{array}{l}750,000 \\
250,000\end{array}$ & $1,000,000$ \\
\hline 29 & $\begin{array}{l}\text { PERSEDIAAN BARANG } \\
\text { KAS }\end{array}$ & $3,000,000$ & $3,000,000$ \\
\hline 30 & $\begin{array}{l}\text { KAS } \\
\text { HUTANG USAHA } \\
\text { PIUTANG } \\
\text { USAHA KAS }\end{array}$ & $\begin{array}{l}100,000 \\
500,000\end{array}$ & $\begin{array}{l}100,000 \\
500,000\end{array}$ \\
\hline & $\begin{array}{l}\text { TOTAL } \\
25,450,000\end{array}$ & \multicolumn{2}{|c|}{$25,450,000$} \\
\hline
\end{tabular}

Tabel 1 Jurnal umum

Dalam Akuntansi UKM, untuk masalah kasus tersebut tidak perlu mengatur rekening perkiraan. Langsung saja masukkan data-data transaksi kedalam jurnal. Berikut tampilan jurnalnya.
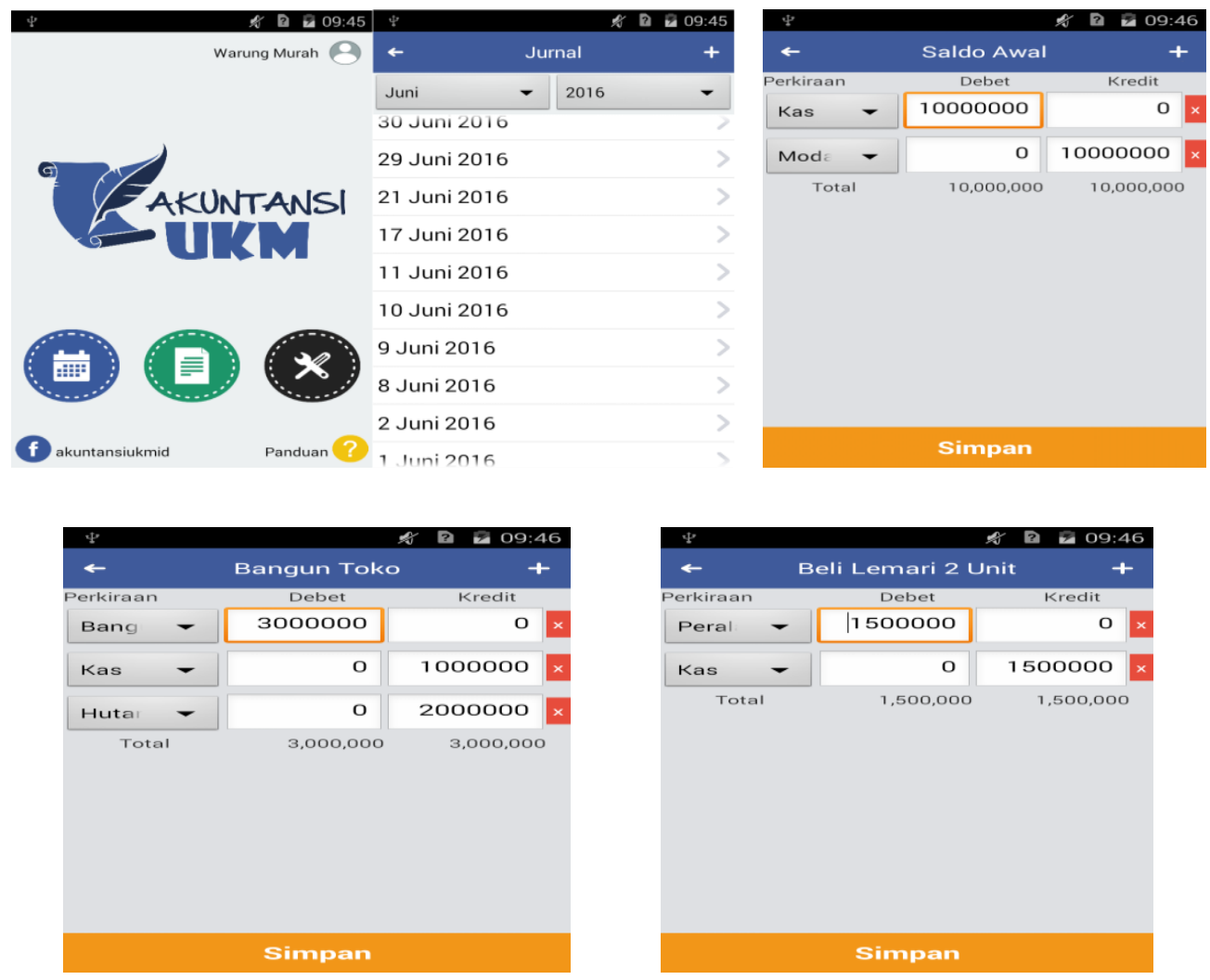


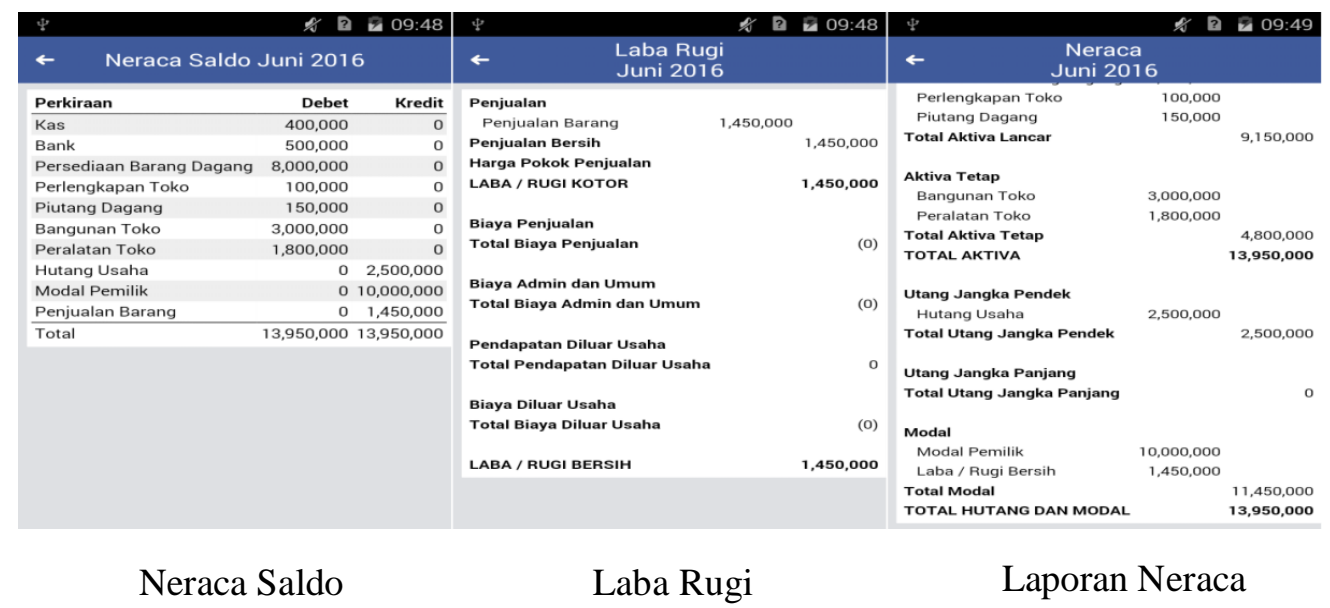

Gambar 2 Aplikasi android akuntansi UMKM

Setiap transaksi yang di jurnalkan, akan terbuat otomatis laporannya. Buku Besar, Neraca Saldo, dan Laporan Laba Rugi pada menu Laporan. Setelah melihat laporan neraca, Akuntansi UKM akan otomatis membuat jurnal baru sebagai saldo awal pada bulan berikutnya.

\section{KESIMPULAN}

Kegiatan pengabdian kepada masyarakat yang dilakasanakan pada hari kamis tanggal 21 Maret 2019 di kelurahan margadana kota tegal yang dihadiri oleh para ibu-ibu pedang kelongtong berjalan dengan lancar, dengan materi tentang Peningkatan Pengetahuan Manajemen Usaha Dengan Menggunakan Aplikasi Android (Akuntansi UMKM) Pada Paguyuban Ibu-Ibu Pedagang Kelontong Kelurahan Margadana. beberapa peserta memiliki antusias terhadap kegiatan pengabdian, karana kegiatan pengabdian seperti ini merupanakan hal pertama yang pernah dilakukan, tingkat penyerapan materi pada kegiatan pengabdian ini masih banyak yang belum memahami bagaimana pencatatan laporan keuangan dengan menggunakan android "akuntansi ukm" sehingga para ibu-ibu pedagang klontong menginginkan untuk adanya tindak lanjut dari acara ini yaitu mengenai pencatatan laporan keuangan secara manual.

Dukungan dari pihak kelurahan margadana juga sangat baik dengan adanya kegiatan pengabdian yang dilakukan oleh dosen akuntansi politeknik harapan bersama, karena akan memberikan nilai positif bagi pihak kelurahan dan para ibu-ibu pedagang kelontong. Paparan materi dibagi menjadi dua sesi yang pertama mengenai menajemen usaha dalam pencatatan laporan keuangannya dan sesi yang ke dua mengenai praktek pencatatan laporan keuangan dengan menggunakan android "akuntansi ukm".

\section{SARAN}

Adapun saran untuk kegiatan pengabdian kepada masyarakat ini diantaranya Diadakannya kegiatan pengabdian masyarakat dengan materi tindak lanjut yang berkaitan dengan kegiatan pengabdian sebelumnya, Sarana dan prasarananya untuk lebih dipersiapkan dengan baik. 


\section{UCAPAN TERIMAKSIH}

Tim pengabdian dari Program Studi DIII Akuntansi Politeknik Harapan Bersama mengucapkan terima kasih yang sebesar-besarnya kepada seluruh pihak yang telah membantu dan mendukung terlaksananya kegiatan pengabdian ini. Secara khusus, ucapan terima kasih diberikan kepada pihak kelurahan margadana yang telah menerima dan bersedia bekerjasama dengan tim. Kemudian kepada institusi dan P3M Politeknik Harapan Bersama yang menjadi penyedia dana acara ini

\section{DAFTAR PUSTAKA}

[1] Musmini, Lucy Sri., 2012, Sistem Informasi Akuntansi Untuk Menunjang Pemberdayaan Pengelolaan Usaha Kecil (Studi Kasus Pada Rumah Makan Taliwang Singaraja), Jurnal Riset Akuntansi, vol. 2 No.1.

[2] Setiawan, 2008, Menerapkan Penggunaan Laporan laba/rugi Pada Usaha Kecil dan Menengah, Jurnal Ilmiah Akuntansi, Volume I No. 2.

[3] Sinarwati, Ni Kadek, 2015, Analisis Faktor-Faktor Yang Mempengaruhi Belum Diterapkannya Pencatatan Keuangan Berbasis SAK ETAP di UMKM, Jurnal Ilmiah Akuntansi dan Humanika, Volume 4 No. 2. Juni 2015.

[4] Stoner, James A.F., Daniel R. Gilbert, R. Edward Freeman, 2009, Management, 6th Edition, New York, Pearson.

[5] Winarni, Sri., 2009, Menerapkan Penggunaan Laporan laba/rugi Pada Usaha Kecil dan Menengah, Jurnal Ilmiah Akuntansi, Volume I No. 2. 